\title{
(NE)PAMIRŠTI VARDAI: VILNIAUS IMPERATORIŠKOJO UNIVERSITETO (1803-1832) PROFESORIAUS AUGUSTO LIUDVIKO BÉCU NUOPELNAI XIX A. PRADŽIOS MEDICINAI
}

\author{
Daiva Milinkevičiūtè \\ Vilniaus universiteto Medicinos fakulteto Sveikatos mokslu institutas
}

Raktažodžiai: Vilniaus imperatoriškasis universitetas, Medicinos skyrius, patologija, fiziologija, vakcina nuo raupų.

\begin{abstract}
Santrauka
Nagrinejjat Vilniaus imperatoriškojo universiteto (VIU) profesoriaus mediko Augusto Liudviko Bécu gyvenimą ir veiklą, iškyla itin produktyvaus ir aktyvaus mokslininko paveikslas. 1803 m. grižžs iš Škotijos, kur buvo universiteto išsiųstas tobulintis, vienas pirmujų Lietuvoje ėmè inicijuoti ir praktikuoti vaikų skiepijimą nuo raupų. $1805 \mathrm{~m}$. buvo Fiziologijos katedros dekanas, nuo $1806 \mathrm{~m}$. vadovavo Patologijos ir higienos katedrai, buvo praktikuojantis gydytojas. Jo darbas apie vaikų skiepijimą nuo raupų buvo pristatytas centrinio Vakcinacijos komiteto (pranc. au Comite central de la Vaccine) Paryžiuje prezidentui Jeanui Antoine Chaptaliui ir A. L. Bécu buvo išrinktas šio komiteto nariu korespondentu. Istoriografijoje jo nuopelnai liko primiršti, todèl pravartu detaliau išsiaiškinti, ką iš tiesų nuveikè A. L. Bécu ir kaip jo mokslinè veikla paveike VIU medicinos mokslo raidą. Straipsnyje nagrinejjamas A. L. Bécu paskaitų turinys, kuris lyginamas su vèlesnio to paties patologijos dalyko dèstytojo Adolfo Abichto paskaitų turiniu, akcentuojama konkurencija su Josephu Franku ir tokios konkurencijos, bei mokslinių diskusijų rezultatai, ieškomi mokslo nuopelnai. A. L. Bécu atvejis detaliai atskleidžia ne tik jo asmeninius iššūkius, bet parodo, su kokiomis problemomis susidūrè IVU, sprendžiant mokslo programų, dėstomų dalykų, naujausių tyrimų taikymo, mokslinių diskusijų ir panašius klausimus ankstyvuoju VIU raidos laikotarpiu. Visa tai analizuojama ir atskleidžiama per vieno unikalaus ir produktyvaus mokslininko santykị su darbo aplinka ir akademiniu pasauliu.
\end{abstract}

Ivadas

Vilniaus imperatoriškasis universitetas (VIU), veikęs 1803-1832 m., siejamas su daug žymių žmonių. Jame mokslinius tyrimus vykdè ir pedagogine veikla užsièmè tokie garsūs mokslininkai kaip Josephas Frankas, Gottfriedas Ernestas Groddeckas, Joachimas Lelevelis ir kiti. Per visą laikotarpi VIU dirbo 135 mokslo vyrai, kuriu 70 buvo kilę iš buvusios Lietuvos Didžiosios Kunigaikštystès (LDK) žemių, o iš 115 dèstytojų net 52 buvo VIU arba jo pirmtakès Lietuvos Didžiosios Kunigaikštystès vyriausiosios mokyklos (toliau-LDKVM) auklètiniai, turèję daktaro laipsnị. VIU dėstė ir nemažai mokslininkų iš užsienio. Deja, dalies reikšmingų laimėjimų pasiekusių universiteto profesorių mokslinis indèlis istoriografijoje nebuvo tinkamai įvertintas arba įvertintas prieštaringai. Vienas tokių pavyzdžių yra vietinio, tačiau prancūzų kilmès profesoriaus Augusto Liudviko Bécu gyvenimas ir mokslinè veikla. Ši prieštaringa asmenybė yra geriau žinoma kaip slaptų studentų draugijų (filomatų ir filaretų) priešas, o jo netikèta ir mistifikuota mirtis nuo kamuolinio žaibo savo namuose aprašyta Adomo Mickevičiaus veikale „Vèlinès“. Mat amžininkai - jo paties studentai prisibijojo A. L. Bécu dẻl jo ryšių su imperine valdžia, kuri draudè ir persekiojo įtartinas draugijas. Tai galètų būti dalis atsakymo ị kelių biografų iškeltą klausimą, kodèl šio produktyvaus ir pažangaus mediko nuopelnai nesulaukè mokslo istorikų dėmesio [1]. Nors atsakymo refleksijų būta, tačiau atrodo, ši asmenybė per mažai žinoma. Ypatingas A. L. Bécu atvejis ne tik atskleidžia daugybę VIU vidaus gyvenimo aspektų, bet ir paraleliai parodo platesni VIU žmonių ir jų mokslinès aplinkos paveikslą, paaiškina, kokiomis aplinkybemis atsirado naujos mokslo šakos, kaip buvo specializuojamasi dalykuose, kokia buvo skirtingų pažiūrų raiškos ir diskusijų išdava. Iš esmès vieno žmogaus santykio su artimiausia mokslo aplinka analizè atskleidžia ir 
iki šiol menkai žinomus, svarbius VIU mokslo pasiekimus.

Tyrimo tikslas - remiantis naujai atrastais šaltiniais, išnagrinèti Augusto Liudviko Bécu mokslinę ir pedagoginę veiklą, aptarti ją platesniame VIU akademinio gyvenimo kontekste. Tokiu būdu bandoma reabilituoti šio svarbaus mokslininko ir pedagogo indèli ne tik VIU mokslo raidai, bet ir XIX a. pr. Lietuvos medicinai.

\section{Tyrimo medžiaga ir metodai}

Straipsnio problematika nagrinèta pasitelkus žmonių gyvenimą ir veiklą analizuojantị aprašomajị biografinị metodą. Analizuojamos asmenybės veiklos ir gyvenimo kontekstas išryškèjo pasitelkus prozopografinị ir kolektyvinès biografijos metodus, kai tiriami visi 115 VIU mokslo žmonių. Tokių metodų principas - analizuoti pavienių individų biografinius duomenis visumoje su kitais. Tokiu būdu galima nustatyti trūkstamus žmonių gyvenimo faktus, pastebèti išskirtinumus ir sukurti tipinio (arba atvirkščiai - unikalaus) akademinio žmogaus paveikslą. Bene svarbiausia tokio tyrimo atrama yra prancūzų istoriko Daniel Beauvois bene pirmoji kompleksiška VIU profesorių biografija [2]. Jo darbo vertimas ị lenkų kalbą buvo papildytas ir išleistas kitu pavadinimu, akcentuojant Vilniaus kultūrinę reikšmę Rusijos imperijoje [3]. Šiame straipsnyje panaudoti pirminiai Lietuvos mokslų akademijos Vrublevskių bibliotekos Rankraščiu skyriuje (toliau - LMAVB RS) saugomi šaltiniai - Augusto Liudviko Bécu paskaitų nuorašai ir publikuoti darbai.

\section{Tyrimo rezultatai}

1771 m. gegužès 3 d. evangeliko reformato Jono Liudviko ir katalikès Karolinos Hein šeimoje Gardine gimęs IVU auklètinis Augustas Liudvikas Bécu buvo tas universiteto darbuotojas, kuriam teko didelè našta ir krūvis, atvykus solidiems mokslininkams iš užsienio, pagrịsti savo mokslinius pasiekimus ir ịrodyti, kad yra tinkamai pasirengęs, vietoje išugdytas mokslininkas. Lietuviškoje istoriografijoje menkinamas A. L. Bécu indèlis ị mokslą: jis vadinamas salonų ir draugijų žmogumi, o tai, kad dėste net kelis dalykus vienu metu, buvo smerkiama, be gilesnès analizès įvardijama kaip „blogas reiškinys“ [4]. A. L. Bécu kilmé neleido jam visavertiškai pritapti nei prie vietinių, nei prie užsienio kolegų - istoriografijoje jis taip ir liko tiesiog prancūzas. Maža to, labai įdomią įžvalgą iliustruojantị analogišką atveji pateikia Ubi universitas- Ibi Europa projekto autoriai, anot kurių, vietiniai Rusijos imperijos mokslininkai dažnai pasišaipydavo iš Prancūzijos ateivių slaviškose žemèse ir priskirdavo juos vadinamajai „vokiečių partijai“ [5]. Biografų nuomone, A. L. Bécu galejo būti vienas pirmujų vietinių, tačiau prancūzų kilmès IVU Medicinos skyriaus auklëtinių [1]. Vitalijos Miežutavičiūtès ir Rimanto Stuko manymu, vietinės kilmės gydytojų, tinkamų pedagoginiam darbui universitete, nebuvo [6]. Ar galima sutikti su šiuo drąsiu teiginiu? A. L. Bécu gimè ir užaugo ATR, mokslus LDKVM baigè aukso medaliu, 1797 m., būdamas 26 metų , gavo viceprofesoriaus vietą, o nuo $1799 \mathrm{~m}$. kaip ekstraordinarinis profesorius dèste patologiją, terapiją, farmaciją, $1812 \mathrm{~m}$. dar ir higieną, medicinos policiją. Tai liudija, jog pakankamai specialistų tuo metu dar nebuvo ir A. L. Bécu teko didelis krūvis. Yra išlikę jo pagal Christophą Wilhelmą Hufelandą desstytos patologijos paskaitų konspektai, kuriuos $1820 \mathrm{~m}$. surašè A. F. Adomavičius. Iš jų sužinoma, kad A. L. Bécu aiškino ligos ir sveikatos definiciją, ragino ieškoti ligos priežasčių, kalbejjo apie mechaninius, cheminius, gyvybinius ir dvasinius (intelektinius) procesus, nagrinejo, kaip susergama ir kaip liga veikia žmogų; apie ịgimtą būklę ir temperamentą, apie ligos eigą ir ligų skirtumus [7]. Aiškinantis A. L. Bécu paskaitų kokybès klausimą, pravartu jas palyginti su vèlesnio patologijos profesoriaus Adolfo Abichto paskaitomis, nes yra išlikę ir 1826-1827 m. A. Abichto po A. L. Bécu skaityto patogenijos ir nozologijos kurso Mikalojaus Nalevaikos (Mikołąj Nalewajko) užrašai, taip pat Jono Berkmano 1831 m. A. Abichto bendrosios patologijos paskaitų konspektai, kurie leidžia sugretinti abiejų mokslininkų dèstymo būdą ir metodus [8].

Priešingai nei jo pirmtakas, A. Abichtas savo dalyką aiškina moderniau: pradeda nuo konkretesnio patologijos apibrèžimo ir išskiria disciplinos šakas, klausia, ar apskritai reikalinga teorija, t. y. patologija, pateikia argumentus už ir prieš, savo išvadas ir literatūros sąrašą [8]. Jis taip pat naudojosi Ch. V. Hufelando darbais, tačiau paskaitų medžiagą papildè ir naujausia literatūra: Johanno Wilhelmo Heinricho Conradi Handbuch der allgemeinen Pathologie (1822), Kurto Sprengelio Pathologiae generalis (1819), Georgo Wilhelmo Christopho Consbrucho veikalais. Kaip ir jo pirmtakas, A. Abichtas aiškina ligos definiciją, jos priežastis ir eigą, tačiau paskaitos pobūdis labiau primena modernias paskaitas, o A. L. Bécu stilius yra pasenęs, būdingas ,prietaru amžiui“. A. L. Bécu savo paskaitose rèmèsi plačiai ịtvirtintu ir pagrịstu, tačiau senu modeliu, nes $\mathrm{Ch}$. V. Hufelando darbai XVIII a. pab. buvo kritikuojami [9]. Per nozologijos (mokslas apie ligų skirtumus ir panašumus - D. M.) paskaitas A. Abichtas kalbẻjo apie fundamentinių ligų klases, išskyrẻ trijų rūšių ligas: „nenormalių jẻgų ligos“, t. y. psichinès, kraujo ir kūno skysčių ligos [10]. R. Kondrato teigimu, XIX a. pr. ligų klasifikacija pagal biologinius simptomus buvo atgyvena, o ligos diagnozuojamos pagal organus [9]. A. Abichto paskaitų turiniui turejo reikšmès ir jo pirmtako pedagoginis indèlis, nes A. L. Bécu dèstè jam daugelị pagrindinių dalykų: anatomiją, anatomijos disekciją, patologiją, farmaciją, chirurginę operaciją, teorinę chirurgiją, akušeriją, 
veterinariją, fiziologiją, higieną ir medicinos policiją [11].

Fiziologijos disciplinos anksčiau universitete nebuvo, nes XVIII a. fiziologija buvo dèstoma arba anatomijos profesorių, arba kartu su bendraja patologija, kaip ir bendroji patologija - kartu su bendraja terapija ir tik XIX a. pr. šiuos mokslus buvo bandoma atskirti [9]. Atrodo, nuopelnus už fiziologijos kurso atsiradimą VIU Josephas Frankas priskyre sau, nes A. L. Bécu užleido Frankams Patologijos katedrą su sąlyga, kad universitetas finansuos jo mokslinę kelionę, kurioje jis tobulintųsi šioje disciplinoje [12]. A. L. Bécu biografų teigimu, jo talentas vystèsi greta J. Franko dèl kolegialios konkurencijos ir didelių ambicijų [1]. J. Franko atsiminimuose tokia konkurencija atsiskleidžia kaip itin priešiška: atrodo, J. Franko pastangomis A. L. Bécu negavo po medicinos daktaro Benedikto Borsuko mirties vakuojančios Teismo medicinos katedros, kuri atiteko Andreas Loebenweinnui, nes, anot J. Franko, A. L. Bécu buvo tinginys ir melagis [12]. Stanislovo Bonifaco Jundzilo manymu, kai kurie kolegos pavydejo A. L. Bécu ir buvo šališki, tačiau jis „giliai išmané medicinos mokslą, bendravime buvo pilnas sąmojų, malonus, geras vyras ir tėvas, uolus ir nepamainomas bičiulis, užjaučiantis visų luomų ligonius ir nusiteikęs jiems padèti medikas“ [13]. Galbūt skirtingų gydymo metodų taikymas sukiršino A. L. Bécu ir J. Franką, kurie 1807 m. gydė sergantị Andriejų Sniadeckị. A. L. Bécu ir Jokūbas Šimkevičius pasipiktino J. Franko gydymo metodais ir stimuliuojančių vaistų nenaudojimu: trečias iškviestas gydytojas padarè išvadą, kad karštis nenuslūgo dèl tokių vaistų perdozavimo, o pasveikus A. Sniadeckiui, ginčas neteko savo pagrindo [13]. Sveika konkurencija tarp šių dviejų mokslininkų skatino juos aktyviai dirbti mokslinį ir pedagogini darbą, vykdyti tyrimus, praktikuotis.

XIX a. pr. gydymas vakcina buvo inovatyvus ir aktualus, nes visoje Europoje siaute galvijų maras. Tuo metu - 1803 m. A. L. Bécu Vilniuje paskelbè darbą $O$ wakcynie czyli tak nazwaney ospie krowiey, kuris reikalauja detalesnès analizès [14]. Ši knyga buvo skirta „besirūpinantiems savo vaikų auklëjimu tèvams“, joje nagrinejjamos užkrečiamosios ligos ir raupų gydymas iki vakcinos atradimo, pateikti argumentai už ir prieš skiepus nuo raupų, taip pat raupų atsiradimo ir paplitimo pasaulyje istorija; aprašytos medikų pastangos atrasti vaistą nuo raupų, komunikacijos galimybės tarp sveikų ir užsikrètusiujų; autorius samprotavo apie klaidingus įsitikinimus, susijusius su supratimu apie raupus [14]. Net ir po 200 metų šie ịsitikinimai išlieka aktualūs. A. L. Bécu ištyrè vakcinos ir skiepijimo atsiradimą, klasifikavimą, skiepijimo procedūros eigą; aiškino, kaip atskirti tikrą vakciną nuo netikros, kaip vakcinuojama, kada laukti rezultatų ir pan., pateikè argumentus už ir prieš vakcinavimą, pristate ,imunologijos tèvo" Edwardo Jennerio ir Wialliamo Woodwillio tyrimus. A.
L. Bécu buvo puikiai susipažinęs su naujausiais šios srities atradimais, t. y. E. Jennerio $1798 \mathrm{~m}$. veikalu An inquiry into the causes and effects of the variolce vaccince, kuriame buvo pagristi trys itin svarbūs teiginiai: kad vakcina yra ta pati liga, tik ịvesta ị žmogaus organizmą jo valia, todèl negali jam pakenkti; kad vakcinacijos perduota liga yra labai lengvos formos ir sveikam žmogui negali pakenkti, kad ja persirgus visam laikui apsisaugoma nuo raupų [15].

Vilnietis medikas knygos autorių pažinojo asmeniškai, o E. Jenneris šią bičiulystę labai vertino. Ši teigini patvirtina Vincento Herberskio mokslinès kelionès metu parašytas laiškas, kuriame teigiama, kad su E. Jenneriu jam padejjo susipažinti ne tiek išskirtiniai rekomendaciniai laiškai, kiek žinia, jog yra iš VIU ir džiaugsmas dèl draugystès su profesoriais J. Franku ir A. L. Bécu [16]. Ši trumpa žinute reiškia, kad VIU medicinos profesoriai buvo gerbiami ir vertinami užsienio kolegų, turèjo autoritetą, mokslinị svorị ir gerą vardą tarp užsienio mokslininkų.

Istoriografijoje pabrèžiamas J. Franko indèlis ị skiepijimą nuo raupų ir Vakcinacijos instituto įsteigimą $1808 \mathrm{~m}$. Vienintelis R. Kondratas mini, kad be J. Franko vakcinaciją taikè A. L. Bécu ir A. Loebenweinnas [9]. Būtent šių medikų pastangomis Vilnių pasieke pirmoji vakcina, o ta, kuri čia buvo gaminama, kaip itin kokybiška ịvertinta E. Jennerio [9]. A. L. Bécu teigimu, nors kai kurių Medicinos skyriaus narių pastangomis nenoreta naudoti vakcinos, vis dèlto 1802 m. balandžio $2 \mathrm{~d}$. ji buvo atsiųsta iš Sankt Peterburgo [17]. Savo darbe autorius akcentavo, kad remiasi ne tik užsienio kraštų tyrèjais, bet ir tūkstančiais savarankiškai atliktų stebejjimų, kurių padarytų dar daugiau, jei ne tèvų baimè iš nežinojimo ir dékojo tiems, kurie skiepijo savo valstiečius (Balinskiai, Grambovskiai, Kosakovskiai, Morikoniai, Pociejai, Straševičiai ir kt.) [14]. 1804 m. rugpjūčio 10 d. laiške iš Paryžiaus Zacharijas Nemčevskis rašè, kad kartu su Jonu Fridrichu Niškovskiu pristate A. L. Bécu darbą apie vakciną centrinio Vakcinacijos komito (pranc. au Comite central de la Vaccine) prezidentui Jeanui Antoine Chaptaliui per akademijos draugijos narị Jacquesą Louisą Doussiną Dubreuilį. Šio reikalo dėka A. L. Bécu buvo išrinktas minèto komiteto nariu korespondentu. Susumavus visus jo nuopelnus, galima drąsiai teigti, kad A. L. Bécu buvo pirmasis ir itin aktyvus vakcinos šalininkas ir vakcinavimo praktikas ne tik IVU, bet ir visoje Rusijos imperijoje.

Verta pridurti, kad $1815 \mathrm{~m}$. darbą apie vakciną išleidęs Motiejus Barankevičius įžangoje, norinti daugiau sužinoti apie skiepijimą nuo raupų skaitytoją, nukreipia būtent ị analizuotą mokslinį A. L. Bécu tyrimą, kas liudija jo svarbą ir nesumažejusį aktualumą praejjus dešimtmečiui. Apie tai, kad šis darbas sulaukè ilgalaikès sèkmès ir turejjo poreikị, liudija 1823 m. gegužès 9 d. kvietimas Mykolui Pelkai-Polinskiui 
dalyvauti viešoje, valdininkams skirtoje paskaitoje Apie raupus ir vakcina ir ragina pakviesti i ją mokytojus [18]. Taigi, A. L. Bécu vakcinacijos darbas buvo populiarinamas ir už VIU mokslinès aplinkos ribų.

Mokslineje spaudoje A. L. Bécu buvo ne ką mažiau produktyvus. 1817 m. žurnale Dziennik Wileński M. Barankevičius recenzavo brošiūrą, kurioje A. L. Bécu prieštaravo kolegos J. F. Niškovskio pranešimo, skaityto viešame universiteto susirinkime, išvadoms [19]. Recenzento ironišku teigimu ir griežta kritika, A. L. Bécu konstravo visiškai naują šiems laikams medicinos mokslų sistemą, vienus medicinos mokslus iškèlè aukščiau kitų, teigè, kad buvimas geru mediku ir chirurgu vienu metu yra „platoniška svajoné“, kad medicina ir chirurgija neturi ir negali būti atskirtos, nes abi sritys gydo, o geras chirurgas privalo gerai žinoti ligų sistematiką - tai ko ir moko medicinos mokslas. M. Barankevičius prikiša A. L. Bécu „daugiau nei diktatorišką toną“, jam nepatiko ir per ilgas (dviejų puslapių) J. F. Niškovskio darbo citavimas; neramus, neaiškus rašymo stilius; netinkamas sąvokų, tokių kaip dogmatizmas, empirizmas, skepticizmas, idealizmas naudojimas, kurios neturi nieko bendro su autoriaus dalyku ir neparodo jo erudicijos [19]. Iš tiesų, A. L. Bécu tekstas nebuvo nukreiptas prieš J. F. Niškovskị, bet veikiau prieš J. Franką, kurio tikslas buvo sujungti medicinos praktiką ir chirurgiją [9]. M. Barankevičiaus nuomone, jeigu autorius savo mokslo aiškinimą pradètų nuo ligoninių ir ligonių žaizdų apžiūrèjimo, taip nerašytų, tačiau jis pamiršo, kad A. L. Bécu taip pat dirbo viešosiose ligoninèse, $1807 \mathrm{~m}$. išleido publikaciją apie jų gerinimą [20]. Jo teigimu, kiekvienas medikas mokosi chirurgijos ir išmano ją gerai, nors ir nepraktikuoja. M. Barankevičius oponuodamas klausé, kaip nepraktikuojant šio dalyko, galima ji gerai išmanyti, nes teoriją lengva pamiršti. Juolab, kad paskaitų metu J. Frankas nuolat mokiniams kartodavo, kad medicina ir chirurgija yra tas pats mokslas ir atskirti jų negalima. Ankstyvoji medicininė J. Franko mintis susiformavo veikiama monistinių ir spekuliatyvių medicininių sistemų (tokių kaip Johno Browno), su kuriomis nesutiko net ir jo tèvas, todèl atrodo, $\mathrm{kad}$ A. L. Bécu priklausè tradicinès medicinos, vyravusios XVIII a. šalininkams [9].

XIX a. pr. prasidèjo svarbūs instituciniai pasikeitimai, kuriais buvo siekiama suvienyti medicinos teoriją su praktika, o tam labai svarbios buvo ir tarp medikų kilusios diskusijos. Johanas Frankas gerai pastebejjo, kad visi medicinos dalykai siejasi tarpusavyje: anatomijos profesorius, mokinąs disekcijos, turi daryti pastabas ir mokinti fiziologijos; fiziologas, aiškindamas apie organų veikimą, ruošia studentus būsimiems patologijos kursams; patologijos profesorius neturi apsiriboti žodiniu ligų apibūdinimu, o jas parodyti ir parengti studentus terapijai [9]. Tokia polemika tarp VIU mediku buvo labiau susijusi su A. L. Bécu ir J. Franko konkurencija, nes pirmasis kritikavo vokiečius, o „Franko mokyklai“ priklausęs M. Barankevičiaus norejjo apginti savo draugą J. F. Niškovskị ir iškelti Frankus [19]. Ne visai konstruktyvią kritiką, kuri kvestionuoja A. L. Bécu mokslinị autoritetą, autorius pateisina tuo, kad savo tekstu norejjo gražiai pajuokauti, nes ir apie rimtus dalykus galima rašyti linksmai [19]. Atkeipiamas dėmesys, kad ši polemika vyko viešoje visuomeninèje erdvèje - spaudoje, vadinasi, ją galèjo stebėti ir ne mokslinès aplinkos žmonès.

Vis dèlto tokia pašaipa nebuvo pelnyta: juk A. L. Bécu pastangomis $1812 \mathrm{~m}$. prancūzų ir rusų karo metu buvo išvengta didelès epidemijos, kai medikui teko spręsti, ką daryti su 40000 mirusių karių palaikais, o vẻliau už ši sprendimą buvo apdovanotas IV laipsnio šv. Vladimiro ordinu [1]. J. Frankas ir čia sugebejjo pašiepti gydytoją, ,gavusi apdovanojimą už tai, kad palaidojo tiek žmonių“, tačiau mieste, kuriame lavonų buvo daugiau nei gyventojų, ši problema buvo labai rimta ir galejo sukelti neigiamų padarinių. Dirbdami ekstremaliomis sąlygomis, gydytojai gebejjo atlikti mokslinius tyrimus, kurie pasitarnavo geresniam ligų pažinimui.

Olgos Mastianicos teigimu, tik VIU profesorius A. L. Bécu, kurio dukterys baigè mokslus Deybelių šeimos privačiame mergaičiu pensione, atkreipé dėmesị ị pensionų buitị [22]. Savo pastebejjimus jis išsake $1815 \mathrm{~m}$. straipsnyje apie mergaičių higieną [23]. Šiuo darbu autorius norejo atkreipti tėvų, pensionų valdytojų, mokytojų dèmesį i pensionų gyvenimo sąlygas, klause, kada ir kokiais tempais reikia šviesti jaunimą, ragino tėvus ir mokytojus nelyginti jaunų žmonių su suaugusiais, nes jaunuoliai yra subtilesni, delikatesni, švelnesni, jautresni [23]. Savo darbe jis rašè apie bendrają higieną (auklèjimo arba fizinè higiena), būstą, aprangą, mitybą, judèjimą, poilsị, miego režimą, bausmes ir apdovanojimus, ligas, moralinę higieną, akcentavo laikotarpio, kuomet reikia pradèti edukaciją, svarbą; išskyrè namų ir viešojo berniuku ir mergaičių auklejjimo skirtumus ir naudą.

İdomu tai, kad A. L. Bécu atkreipé dèmesị ị tinkamą mitybą ir pateikè savo rekomendacijas: draudè vartoti kavą, arbatą pusryčiams ir pavakariams (vietoj to rekomendavo pieną, košes, karštą alų), pavakarių meniu esą turètų būti sausas (sūris, duona, sviestas, vaisiai), o pusryčių - šiltas, virtas. Agitavo vengti bet kokio valgymo ne laiku. Jo teigimu, nèra nieko sveikesnio, kaip jausti alkị iki tam tikro valgymo meto, pasninkauti: per pietus reikia valgyti sočiai, vakarienè turi būti lengva, maistas itin šviežias (rūkytus gaminius valgyti retai, vengti aštrių ir sūrių prieskonių, padažų, marinatų). Dèl tokių modernių ir šiais laikais itin aktualių patarimų A. L. Bécu galima drąsiai vadinti dietologijos pradininku Lietuvoje. Jis moke, kad skalauti burną ir valytis dantis reikia kiekvieną dieną visą gyvenimą, teatrai ir viešosios pramogos, 
pokyliai ir visokie vakariniai pasibuvimai moraline prasme jaunam amžiui kenkia, nes gadina kasdienybès reguliarumą, netenkama jëgų ir sveikatos. Autorius suprato režimo svarbą, kas šiais laikais yra moksliškai pagrịstas faktas [23]. Nepaisant šio svarbaus A. L. Bécu darbo, daugiausia nuopelnų higienos srityje taip pat priskiriama J. Frankui.

\section{Išvados}

1. Apibendrinant pateiktą atveji, reikia konstatuoti, kad A. L. Bécu pastangomis VIU vienas pirmujų Rusijos imperijoje ėmé diegti raupų skiepijimą praktikoje ir neatsiliko nuo kitų Europos kraštų. Šis jo milžiniškas darbas yra itin reikšmingas ir teigiamas indèlis i mokslo plètrą Lietuvoje.

2. Pažymètina, kad XVIII a. pab. Vilniuje labai trūko gerų gydytojų ir medicininès literatūros, todèl A. L. Bécu veikla, apimanti tiek medicinos praktiką, tiek teoriją yra labai svarbi ir gali būti lyginama su žymiujų Frankų, kurie, beje, turèjo nepalyginamai geresnes sąlygas tobulèti užsienyje, nei A. L. Bécu Vilniuje, darbais. $1803 \mathrm{~m}$. IVU jau turejjo gerai paruoštą vietinį medicinos specialistą, kuris savo kompetencijas sugebėjo atskleisti ir mokslo darbais reaguoti i i iššǔkius, atvykus profesionalams iš Vakarų, jo dèka buvo išauklèta nauja VIU medicinos specialistu karta.

3. A. L. Bécu rašè mokslinius ir mokslo populiarinimo darbus, priklausè užsienio mokslo draugijoms, buvo aktyvus VIU bendruomenès narys, kurio veiklai atsiskleisti neleido netikèta ir dramatiška $1824 \mathrm{~m}$. rugsèjo $26 \mathrm{~d}$. jo namuose ištikusi mirtis. 53 metų prancūziškos kilmès, bet tikro vilniečio, VIU profesoriaus, palaidoto Vilniaus Rasų kapinèse, nuopelnai medicinos srityje dar nèra iki galo ištirti, o jo asmenybė ir gyvenimas verti atskiro tyrimo.

\section{Literatūra}

1. Jakubowska A, Brzuchalski MA, Pliszkiewicz M, Jeśman Cz. Profesor August Becu - doktor z Dziadów. Przyczynek do rozważań nad początkami medycyny nowożytnej na Wileńszczyźnie, Forum Bibliotek Medycznych, 2015; 2(16): 268-279.

2. Beauvois D. Szkolnictwo polskie na ziemiach litewsko-ruskich, 1803-1832. Rzym, Lublin 1991.

3. Beauvois D. Wilno polska stolica kulturalna zaboru rosyjskiego 1803-1832. Wrocław 2012.

4. Bumblauskas A.(red.), Butkus Z. ir kt. Alma Mater Vilnensis: Vilniaus universiteto istorijos bruožai. Vilnius: Vilniaus universiteto leidykla, 2009:1060.

5. Андреева АЮ, Посохова СИ. (ред.). Университет в Российской империи XVIII - первой половины XIX века. Москва, 2012.

6. Miežutavičiūtè V, Stukas R. Higienos dèstymo pradžia Vilniaus universitete. Medicinos teorija ir praktika, 2013;19 (3).

7. Treść patogenii Hufelanda dawaney p. Aug. Bécu. LMAVB RS
1820; f. 9-256.

8. Patogenia. Część 1, 1826-1827. LMAVB RS, f. 9 - 284.

9. Kondratas RA. Joseph Frank (1771-1842) and the development of clinical medicine. A study of the transformation of medical thought and practice at the end of the 18th and the beginning of the 19th centuries. Harvard University, Massachusetts 1977.

10. Nosologia. 1826-1827, LMAVB RS, f. 9-200. Abicht A. Praelectionum pathologiae generalis, libri duo, Vilnae, 1831-1833.

11. Papiery tyczące się Uniwersytetu Wileńskiego r. 1815-1819. VUB RS, f. 2, b. KC-2, 1. 37.

12. Frankas J. Vilnius XIX amžiuje: atsiminimai (Kn. 1). Vilnius: Mintis, 2013.

13. Pamiętniki ks. Stanisława Jundziłła profesora uniw. Wileńskiego, wydał Antoni M. Kurpiel, W Krakowie: nakładem Akademii Umiejętności, 1905.

14. Becu A. O wakcynie czyli tak nazwaney ospie krowiey. Wilno, 1803.

15. Riedel S. Edward Jenner and the history of smallpox and vaccination. Proc. Baylor University Medical Center 2005; 18(1):21-25. https://doi.org/10.1080/08998280.2005.11928028

16. Orig.: "Takowa introdukcyja byla dostateczna do pozyskania nie tylko znajomości tego męża, lecz nawet do wyiednania podchlebney dla mnie przyjaźni". Žr.: Listy i raporty do Wincentego Herberskiego adjunkta Uniw. Wil. z podróży zagranicznej w latach 1818-23 do Rządu Uniw. i do dziekana Oddz. Nauk lekarskich, 1817-1823. VUB RS, f. 2, b. KC-399, 1. 44.

17. Gazeta Literacka Wileńska (1806 styczeń-grudzień). Wilno 1806;1(37):175.

18. Mykolui Pelkai Polinskiui rašyti laiškai. LMAVB RS, f. 151677, 1. 2.

19. Barankiewicz M. Na pismo O łączeniu medycyny z chirurgią przez Augusta Bécu, profesora patologii i higijeny, w Dzien. Wileń. Nr 31 umieszczone, odpowiedź, Warszawa, 1817.

20. Becu A. Rozprawa o doskonałości szpitalów miana na publiczném posiedzeniu przy rozpoczęciu kursów rocznych w Imperatorskim Wileńskim Uniwersytecie dnia 15. 7bra 1807 roku. Wilno 1807:37.

21. Kaczkowski K. Wspomnienia z papierów pozostałych po ś.p. Karolu Kaczkowskim. Nakł. księgarni Gubrynowicza i Schmidta 1876:68.

22. O. Mastianica. Privatūs mergaičių pensionai Lietuvoje XIX a. pirmoje puseje. Magistro darbas. Vilnius, 2005:86.

23. Becu A. O hygienie wieku młodzienczego z wyłożeniem jednego tey nauki rozdziału o edukacyi panien na pensyi. Dziennik Wileński 1815; I(4).

\section{(UN)FORGOTTEN NAMES: MEDICAL MERIT OF VILNIUS IMPERIAL UNIVERSITY (1803-1832) PROFESSOR AUGUST LUDVIK BÉCU D. Milinkevičiūtè}

Keywords: Vilnius Imperial University, Department of Medicine, pathology, physiology, smallpox vaccine. 
Summary

Examining the life and activities of the professor of Vilnius Imperial University (hereinafter - VIU), doctor August Ludvik Bécu, a picture of a highly productive and active scientist emerges: returning from Scotland, where he was sent by the university to improve, one of the first in Lithuania to initiate and practice vaccination against smallpox in children. He was not only a practicing physician but also dean of the Department of Physiology, from 1806 and headed the Department of Pathology and Hygiene, was a practicing physician. Bécu's work on smallpox vaccination of children was presented to its President, Jean Antoine Chaptal, at the Central Vaccination Committee in Paris and elected co-member of that committee. Unfortunately, in historiography, his merit remained forgotten, so it is useful to find out in detail what A. Bécu did and how his scientific activities affected the development of me- dical science at VIU. The article examines the content of his lectures, which is compared with the content of later lectures by Adolf Abich, a lecturer in the same subject of pathology, emphasizes the competition and the results of such competition, and scientific discussions with J. Frank. The case of A. Bécu reveals in detail not only his challenges but more importantly, the problems faced by the IVU in dealing with scientific programs, subjects, application of the latest research, scientific discussions, and similar issues in the early development of VIU. All of this is analyzed and revealed through the relationship of one unique and productive researcher to the work environment and academia.

Correspondence to: daiva.milinkeviciute@mf.vu.lt

Gauta 2021-03-05 